\title{
Review on Production of Single-Cell Protein from Food Wastes
}

\author{
Nura Abdullahi ${ }^{1, a, *}$, Munir Abba Dandago ${ }^{1, b}$, Alkasim Kabiru Yunusa ${ }^{1, c}$ \\ ${ }^{1}$ Department of Food Science and Technology, Kano University of Science and Technology, Wudil, P. M. B. 3244, Kano State, Nigeria. \\ *Corresponding author

A R T I C L E I N F O A B S T R A C T \\ Reviwe Article \\ The roles of protein in bodybuilding and the regulation of biological processes are important in \\ sustaining life. A large amount of protein is required by both humans and animals and this cannot \\ be supplied by only conventional sources. This is because of the rapid increase in world population. \\ The present sources of protein will not meet global protein demand in years to come. Scientists \\ Received : 23/07/2020 \\ Accepted : 01/03/2021 \\ explore the production of single-cell protein (SCP), as an alternative source of protein, through the \\ utilization of wastes and low-value materials. SCP can supply high-quality protein containing both \\ essential and non-essential amino acids that can be utilized by humans and animals. Protein from \\ microbial biomass is cheaper than animal proteins because the substrates used in the production are \\ generally cheaper and more readily available. Moreover, the production process does not require \\ arable land and the entire process can be completed within a short time. This article reviewed the \\ process of SCP production. Different raw materials used in the production and variations in growth \\ media preparation methods were discussed. Various sources of fermentation microorganisms and \\ their potential substrate were reviewed. Growth media enrichment using different carbon, nitrogen, \\ and mineral sources was also discussed. \\ Keywords: \\ Single-cell protein \\ microorganisms \\ Biomass \\ Amino acid \\ Food
}

a@nurafst@gmail.com (iD) https://orcid.org/0000-0001-9143-6560 c@yalkasimkabiru@gmail.com iD https://orcid.org/0000-0002-9917-5673 dandago223@gmail.com

iD https://orcid.org/0000-0003-4840-9553

\section{Introduction}

Proteins are the building blocks of the body and play essential roles in the regulation of biological processes including information processing (Shahi et al., 2017). Protein is used by humans and animals as a source of nitrogen and essential amino acids; for bodybuilding and repair, regulation of biochemical processes, and synthesis of energy under certain conditions (Ritala et al., 2017; Milala et al., 2018). The term Single Cell Protein (SCP) was first coined in 1966 by Carol Wilson to described protein from microbial biomass (Nasseri et al., 2011). SCP is a dead, dried microbial cell mass of bacteria, fungi, and algae (Nalage et al., 2016). It is also regarded as proteins extracted from only microorganisms (Shete and Raut, 2018).

Population growth, poverty, and starvation force humans to explore additional sources of food to meet-up with the accelerated population growth (Kapilan et al., 2018; Reihani and Khosravi-Darani, 2019). By 2050 the world population will require 1,250 million tonnes of meat and dairy per year to meet global protein demand at present consumption levels. Achieving this will be very difficult without exploring other sources. The present trend in the production of protein is the cultivation of microbes and algae that can provide the required balance of essential amino acids and contain more than $30 \%$ protein in their biomass (Ritala et al., 2017). The potential of some bacterial and fungal species in the production of single-cell protein was discovered some twenty years ago (Reihani and Khosravi-Darani, 2019). The Conversion of food wastes into valuable products is fascinating and becoming more economically viable. It safeguards public health through useful and innovative recycling methods (Gervasi et al., 2018). Protein scarcity account for acceptance of SCP and its role in the provision of safe food and feed was reported by many (Reihani and Khosravi-Darani, 2019).

Production of SCP is through fermentation, a biochemical process that breakdown complex substrates into simpler compounds by the action of microorganisms such as bacteria and fungi. Temperature, $\mathrm{pH}$, nature, and composition of the medium, gas composition, and operational system affect the fermentation process (Mensah and Twumasi, 2017). SCP production was commercialized for decades, but research on fermentation optimization and study on potentials of many wastes and 
low-value materials in the production of SCP is still interesting to many researchers (Reihani and KhosraviDarani, 2019).

In the production of SCP, microorganisms utilize inexpensive feedstock or waste as carbon sources and grow into biomass rich in protein and amino acids (Nasseri et al., 2011). Feedstock and waste used in the production are mostly from agricultural sources and the product can be used as a protein supplement in either food or feed (Mensah and Twumasi, 2017; Anichebe et al., 2019). Agricultural wastes are rich in cellulose which is a suitable carbon source for some microorganisms. Production of SCP using agricultural wastes through fermentation is one of the important approaches to curtail protein shortage. The efficient utilization of waste from food industries will also maximize production profit (Zhou et al., 2019). In addition, many harmful substances are neutralized and environmental pollutions are also reduced. The aim here is not only to save the environment but also to produce a substance that is economically valuable (Spalvins et al., 2018a).

The shorter generation time in microorganisms allows for easy transformation and substrate utilization. SCP production does not require agricultural land and cannot be affected by season or climate because the process can be controlled without many difficulties (Yunus et al., 2015; Suman et al., 2015).

SCP is an important foodstuff, rich in protein, and also contains other vital nutrients such as lipids, carbohydrates, nucleic acids, non-protein nitrogenous compounds, vitamins, and inorganic substances (Suman et al., 2015; Nalage et al., 2016). Biomass of microbial protein contains both essential and nonessential amino acids and minerals such as phosphorus, potassium, sodium, calcium, etc. (AlHadithi et al., 2018). High nucleic acid content and slow digestibility will limit the utilization of SCP as a replacer to conventional protein. The possibility of developing allergic reactions by some individuals is also alarming (Nasseri et al., 2011).

\section{Food Wastes as Substrates for Production of SCP}

Food processing and agricultural wastes are the main raw materials for the production of SCP; tons of wastes are generated from the consumption of oranges, bananas, pineapples, and watermelons (Oshoma et al., 2017). Lignocellulose wastes from millions of tons of wheat, rice, and corn processed globally are potential raw materials for SCP production (Said et al., 2019). It can be produced from wheat bran (Yunus et al., 2015), orange peel (Milala et al., 2018; Zhou et al., 2019), banana peel (Jiru and Melku, 2018; Oshoma et al., 2017), pineapple waste (Mensah and Twumasi, 2017; Anichebe et al., 2019), potato, paper, and corncob starch waste residue (Al-Hadithi et al., 2018), rice straw, bagasse, and coffee husk (Said et al., 2019), tofu and cheese wastes (Putri et al., 2018), bele's fruit peel (Haddish, 2015), pulp, juice, and peel of lemon and orange (Mahan et al., 2018), potato wastewater and glycerol (Kurcz et al., 2018), sugarcane bagasse (Samadi et al., 2016), papaya (Rajendran et al., 2018), sugar beet pulp, cassava, coconut, grape and mango wastes (Suman et al., 2015).

Liquid substrates reported are cheese whey (Yadav et al., 2015; Monkoondee et al., 2016), non-dairy creamer wastewater (Dewi et al., 2017), sugar refinery wastewater (Saejung and Salasook, 2020), pineapple peel juice, and rice washing water (Mujdalipah and Putri, 2020), latex rubber sheet wastewater (Kornochalert et al., 2014), dephenolized olive mill wastewater (Giavasis and Petrotos, 2016), sugarcane molasses (Hansen and Cheong, 2019; Spalvins et al., 2018a), soybean molasses (Gao et al., 2012), deproteinized leaf juice (Chanda and Chakrabarti, 1996; Spalvins et al., 2018a), food waste-derived volatile fatty acids (Wainaina et al., 2020), waste milk (Myint et al., 2020), municipal wastewater treatment effluent (Steinberg et al., 2017), food processing wastewater (Xu et al., 2020). Urban bio-waste is also a potential substrate for SCP production after anaerobic digestion; methane produce during digestion can serve as a carbon source in the production of SCP rich in essential amino acids (Khoshnevisan et al., 2019). The use of methane (from natural gas) as a sole source of carbon in the SCP production was reported by Ritala et al. (2017) and Shete and Raut (2018).

Production of SCP from processing wastewater improves the wastewater quality by neutralizing materials that are harmful to the environment (Giavasis and Petrotos, 2016; Spalvins et al., 2018a; Saejung and Salasook, 2020), also save the huge amounts required for their disposal (Kosseva, 2009). Substrates in liquid wastes are readily digestible and can easily be converted into biomass (Hülsen et al., 2019).

\section{SCP Production Process}

The production process of SCP varies according to the substrate. The operations involved in the production are media preparation, sterilization of the media, media enrichment, inoculum isolation and growing, inoculation and incubation, harvesting, and protein content determination.

\section{Media Preparation}

The primary raw materials used in the production of growth media for SCP production are fruits and vegetable wastes, lignocellulose materials, and liquid wastes.

\section{Media Preparation Using Fruit and Vegetable Wastes}

Dry, wet, and direct methods are used in the production of SCP growth media from fruits and vegetable wastes. In the dry method, the collected waste is thoroughly washed using sterile distilled water and dried, it is then crushed into a fine powder and blended with distilled water in a ratio of $1: 4$. The blend is then passed through a muslin cloth to collect fruit waste broth to be use as a fermentation medium (Oshoma et al., 2017). The media is then heat-treated at $160^{\circ} \mathrm{C}$ for 30 minutes (Jiru and Melku, 2018).

In the wet preparation method, the fresh fruit waste is thoroughly washed with clean water or $2 \% \mathrm{H} 2 \mathrm{SO} 4$ solution, then with distilled water. The waste is then cut into small pieces and pulverized using a sterilized blender. The extract is then collected by filtration and use as a fermentation medium (Mensah and Twumasi, 2017; Anichebe et al., 2019; Rajendran et al., 2018) after sterilization at $121^{\circ} \mathrm{C}$ for 15 minutes (Mahan et al., 2018). 
In the direct method, the collected fruit or vegetable wastes are thoroughly washed with clean water (Yousufi, 2012). Acid hydrolyzed using $10 \% \mathrm{HCl}$ performs (Ahuja and Kumari, 2019) to breakdown polysaccharides into monosaccharides if the microorganism is deficient in cellulase and/or amylases (Azam et al., 2014), this enriches the media with more readily available sugars (Mondal et al., 2012). pH adjustment to neutral before sterilization was reported by Mahan et al. (2018) while preparing fresh oranges and lemon peels. The prepared media is then sterilized at $121^{\circ} \mathrm{C}$ for 15 minutes before inoculation (Yousufi, 2012; Mahan et al., 2018), a longer heating time (45 minutes) was reported by Khan et al. (2010), this was possibly done to thermally breakdown the polysaccharides into simple sugars as reported by (Jiru and Melku, 2018).

\section{Media Preparation Using Lignocellulose Wastes}

Lignocellulose materials are thoroughly washed with distilled water, oven-dried, crushed into powder, and sifted through a fine mesh (Samadi et al., 2016; Said et al., 2019). Acid and bio-digestion are employed to breakdown complex polysaccharides in lignocellulose materials. A thermal pretreatment is achieved by autoclaving at $121^{\circ} \mathrm{C}$ for 60 minutes (Said et al., 2019). Acid digestion $\mathrm{n}$ using $\mathrm{HCl}$ at $75^{\circ} \mathrm{C}$ is employed particularly when the culture organism lack enzymes responsible for breaking down cellulose materials (Haddish, 2015). Bio-digestion (bio-pulping) using fungi is also employ to breakdown woody substrates (Khoshnevisan et al., 2019). The pre-treated materials are then washed with distilled water and oven-dried (Said et al., 2019). The powder is then blended with distilled water in the ratio 1:4 before autoclaving (Oshoma et al., 2017). The summary of growth media preparation methods using different solid substrates is presented in Figure 1.

\section{Media preparation using liquid waste}

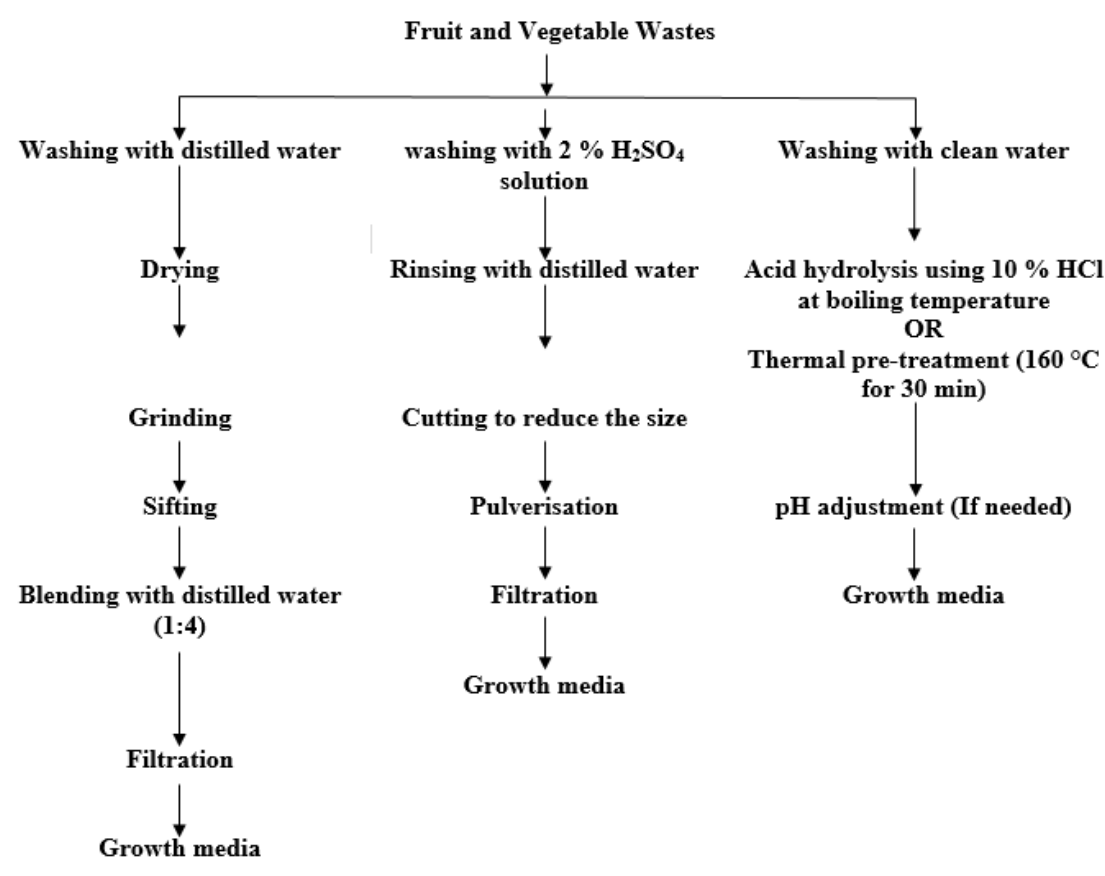

Liquid wastes used as a substrate for SCP production are either pasteurized or sterilized and inoculated with the culture organism (Kurcz et al., 2018; Putri et al., 2018). Anaerobic digestion is used as a preparatory operation in liquid substrates such as urban bio-waste (Khoshnevisan et al., 2019). pH adjustment using acidic effluent was the only preparatory operation reported by Monkoondee et al. (2016) in cheese whey. Xu et al. (2020) combine sterilization and $\mathrm{pH}$ adjustment in acid wastewater from food processing. Similar pre-treatment was also reported by Saejung and Salasook (2020) in the production of biomass using sugarcane processing wastewater. Filtration and sterilization were reported by Mujdalipah and Putri (2020) in pineapple peel juice and rice washing water. Giavasis and Petrotos (2016) reported dephenolized by microfiltration and condensation by reverse osmosis as pre-treatment operations for olive mill wastewater.

\section{Enrichment of the Media}

SCP yield depends on the type of substrates and the composition of the growth medium (Haddish, 2015). The media are enriched with different materials to serve as either carbon, nitrogen, or mineral source. Materials used as carbon source include sucrose, fructose, lactose, starch, mannose, maltose, cellulose, and galactose (Anichebe et al., 2019), potato starch (Zhou et al., 2019), glycerol (Kurcz et al., 2018), glucose (Ardestani and Alishahi, 2015). Nitrogen sources are sodium nitrate, potassium nitrate, ammonium nitrate (Anichebe et al., 2019), soybean cake (Rajendran et al., 2018; Zhou et al., 2019), diammonium phosphate (Yunus et al., 2015), Urea, Ammonium Sulphate, NPK (Said et al., 2019), seawater (Putri et al., 2018). 
Protein yield in many microbial species was reported to be increased by mineral supplementation. The performance yield of $A$. niger was improved in a growth medium supplemented with minerals (Oshoma et al., 2017). Protein yield improved in Saccharomyces cerevisiae cell in a growth medium supplemented with $\mathrm{MgSO}_{4}, \mathrm{NaCl}, \mathrm{CaCl}_{2}$ and $\mathrm{KH}_{2} \mathrm{PO}_{4}$ (Haddish, 2015; Kapilan et al., 2018), and that of Rhodococcus opacus in a medium supplemented with $\mathrm{K}_{2} \mathrm{HPO}_{4}, \quad \mathrm{FeCl}_{3}, \quad \mathrm{MnSO}_{4} \cdot \mathrm{H}_{2} \mathrm{O}, \quad \mathrm{CuSO}_{4} \cdot 5 \mathrm{H}_{2} \mathrm{O}$, $\mathrm{ZnSO}_{4} \cdot 7 \mathrm{H}_{2} \mathrm{O}, \mathrm{KCl}, \mathrm{H}_{3} \mathrm{BO}_{3}$ (Mahan et al., 2018). The combined use of glucose, $\mathrm{MgSO}_{4}$, and $\mathrm{KH}_{2} \mathrm{PO}_{4}$ increases protein yield in Aspergillus niger PTCC5012 (Ardestani and Alishahi, 2015). Too much supplementation can affect microbial growth; Mensah and Twumasi (2017) reported a decrease in the growth of Saccharomyces cerevisiae in pineapple waste medium containing a higher amount of sugar. The high concentration of sugar causes osmotic dehydration and prevent cell division.

\section{Sterilization of Growth Media}

Growth media are autoclaved at $121^{\circ} \mathrm{C}$ for 15 minutes before inoculation (Kapilan et al., 2018; Mahan et al., 2018). Sterilization of prepared media can improve the growth of the chosen microorganism but can be optional, according to Gervasi et al. (2018) who reported successful production of biomass in a medium consist mixture of food wastes without any (thermal and/or chemical) pretreatment.

\section{Inoculum Isolation and Growing}

Most of the inoculums used in SCP production are isolated from food and the environment. Oshoma et al. (2017) isolated Aspergillus niger from an onion bulb spoiled at ambient conditions. Saccharomyces cerevisiae which is the most common organism used in SCP production can be isolated from palm wine (Mensah and Twumasi, 2017), rotten tomato (Milala et al., 2018). Saccharomyces cerevisiae isolated from bread produced biomass rich in essential amino acids (Ahuja and Kumari, 2019). The laboratory grew Saccharomyces cerevisiae used in a beles' fruit peel (Haddish, 2015) and sugarcane bagasse (Samadi et al., 2016). Trichoderma viride can be isolated from soil (Anichebe et al., 2019), also Candida lusitaniae (Shete and Raut, 2018), and Raoutella ornithinolytica (Al-Hadithi et al., 2018). Torula yeast (Cyberlindnera $\mathrm{sp}$ ) isolated from sawdust performed well in banana peel medium supplemented with $\left(\mathrm{NH}_{4}\right)_{2} \mathrm{SO}_{4}$ as nitrogen (Jiru and Melku, 2018). Pure culture of inoculum used by some researchers. Pure culture of Aspergillus oryzae, Trichoderma koningii, and Candida tropicalis were used by Zhou et al. (2019) in the production of SCP from orange waste. Pure culture of bakers' yeast (Saccharomyces cerevisiae) was reported to be efficient in the production of SCP from banana (Kapilan et al., 2018).

Inoculums are multiplied by growing on generalpurpose growth media such as Nutrient agar or potato dextrose agar before inoculation into the prepared medium (Samadi et al., 2016; Ahuja and Kumari, 2019). Synergy and antagonism between fermentation organisms affect SCP quality (Zhou et al., 2019). Inoculum size and age, incubation period and temperature, and moisture to substrate ratio affect SCP production (Yunus et al., 2015).

\section{Inoculation and Incubation}

After autoclaving and enrichment (if required), the growth medium is inoculated with the microbial colony that will grow into biomass. Optimum fermentation temperatures range from 28 to $37^{\circ} \mathrm{C}$, and incubation time is 48 hours and above depending on the organism (Rajendran et al., 2018; Milala et al., 2018; Ahuja and Kumari, 2019).

Inoculum levels influence the growth of microorganisms (Koutsoumanis and Sofos, 2005; Xu et al., 2020) by affecting reference time to detection (Bidlas et al., 2008), lag time (Robinson et al., 2001), and microbial enzymes production (Dinarvand et al., 2017; Ilgin et al., 2020). The lower the inoculum level the higher the $\mathrm{pH}$ and $\mathrm{a}_{\mathrm{w}}$ levels for optimum growth (Skandamis et al., 2007). Inoculum size and age affect the fermentation process and protein content of SCP (Reihani and Khosravi-Darani, 2019). Excessive inoculation above optimum does not increase the protein content of biomass. The report of Hongpattarakere and H-Kittikun (1995) indicated that increasing inoculum size above $5 \%$ has no effects on the protein content of Schwunniomyces castellii B5285 biomass grown in cassava starch. Patthawaro and Saejung (2019) also reported no significant difference in the Rhodopseudomonas faecalis biomass produced at 20 and $30 \%$ inoculum levels.

Yunus et al. (2015) reported maximum protein yield in Candida utilis and Rhizopus oligosporus biomass grown in wheat bran at $10 \%(\mathrm{v} / \mathrm{w})$ inoculum size using 48 hours old culture. Inoculum size of $4 \%(\mathrm{v} / \mathrm{v})$ was found to be suitable for optimum protein production in Candida utilis grown in fruit waste extract in submerged fermentation (Munawar et al., 2010). Maximum production of Rhizopus oligosporus mycelium with higher protein content was achieved at $7.5 \%(\mathrm{v} / \mathrm{v})$ inoculum size (Mahat and MacRae, 1992). A higher optimum inoculum level $(20 \%)$ was reported by Xu et al. (2020) in acid tolerance Methylocapsa acidiphila. In addition to protein yield, inoculum size significantly affects microbial enzyme synthesis during solid-state fermentation (Kosseva, 2013). The rate of cellulase enzyme production by Trichoderma harzianum grown in wastewater was found to be ideal at $2 \%(\mathrm{v} / \mathrm{w})$ inoculum size (Alam et al., 2008).

\section{Harvesting and Protein Content Determination}

After incubation, the fermented broth is subjected to a high-speed centrifuge (4000-6000 rpm) for 20 minutes. Sediments are collected and dried before crude protein content determination (Samadi et al., 2016; Kapilan et al., 2018). Much advancement is achieved in SCP production but harvesting and purification after production remain a problem (Valverde-Pérez et al., 2020). The Possibility of harvesting methanotrophic biomass by dewatering using forward osmosis was reported by Valverde-Pérez et al. (2020). The Protein content of the harvested biomass is determined using micro Kjeldahl method (Milala et al., 2018; Jiru and Melku, 2018; Rajendran et al., 2018) or Lowry's method (Ahuja and Kumari, 2019) 


\section{Potential Organisms for the Production of SCP}

Microorganisms occupied an essential position in the history of the human diet, their roles in early processing operations were recognized in the production of fermented food (Nalage et al., 2016). The most used organism in the production of SCP is Saccharomyces cerevisiae. The organism can grow well in different media with or without supplementation and biomass from this organism can contain up to $64 \%$ protein in supplemented medium (Haddish, 2015). Trichoderma reesei produced 22\% crude protein in solid-state fermentation using rice straw as a substrate (Said et al., 2019). Candida lusitaniae characterized with higher protein content and less nucleic acid content, the protein produced by this organism will be good for food and feed production (Shete and Raut, 2018). Rhizopus oligosporus and Candida utilis were used in the production of SCP using wheat bran (Yunus et al., 2015). Biomass of protein can be produced from Rhodococcus opacus using pulp, juice, and peel of orange and lemon extracts as growing media (Mahan et al., 2018). More than $50 \%$ of the protein was realized from Chlorella sp. biomass using tofu waste as a growing medium (Putri et al., 2018). Anichebe et al. (2019) reported an increase in growth and protein yield in Trichoderma viride cultured in pineapple and banana peel extracts. Higher biomass content was observed in both banana and pineapple medium when cellulose was used as a carbon source. Protein-rich biomass could be produced using municipal wastewater by growing Rhodopseudomonas sp. CSK01 under neutral pH (Saejung and Thammaratana, 2016). Biomass of Candida utilis ATCC 9950 was produced in medium of potato wastewater enriched with glycerol as carbon source (Kurcz et al., 2018)

\section{Conclusion}

SCP as an alternative to animal protein can supply adequate quality protein at an affordable cost. Many microorganisms were reported to grow well in many low value substrates and wastes. Saccharomyces cerevisiae is the most reported organism used in the production of SCP. The biomass of this organism can contain more than $60 \%$ protein and other important nutrients such as carbohydrates, fat, and minerals including essential ones. Higher nucleic acid content and slow digestibility after consumption can limit the utilization of SCP. Moreover, the possibility of developing allergic reactions by some individuals can also minimize it's consumption. Another serious challenge that was not reported by researchers in this field is the tendency of spore formation by some persistent microorganisms during drying of the harvested biomass.

\section{References}

Ahuja S, Kumari P. 2019. Production of Single Cell Protein from Fruit and Vegetable Waste using Saccharomyces cerevisiae. International Journal of Current Microbiology and Applied Sciences 8, 114-124. https://doi.org/10.20546/ ijcmas. 2019.802.014

Al-Hadithi OAH, Al-rawi DF, Qais MAA. 2018. Single cell protein production by soil Raoutella ornithinolytica incubated on waste potato, paper and corn cob products. Online Journal of Veterinary Research 22: 1137-1144.
Alam MZ, Muyibi SA, Wahid R. 2008. Statistical optimization of process conditions for cellulase production by liquid state bioconversion of domestic wastewater sludge. Bioresource Technology 99, 4709-4716. https://doi.org/10.1016/ j.biortech.2007.09.072

Anichebe CO, Uba, BO, Okoye EL, Onochie CC. 2019. Comparative Study on Single Cell Protein (SCP) Production by Trichoderma Viride From Pineapple Wastes and Banana Peels. International Journal of Research Publications 23. https://doi.org/10.2139/ssrn.3448990

Ardestani F, Alishahi F. 2015. Optimization of Single Cell Protein Production By Aspergillus Niger Using Taguchi Approach. Journal of Food Biosciences and Technology 5: 73-79.

Azam S, Khan Z, Ahmad B, Ali J. 2014. Production of Single Cell Protein from Orange Peels Using Aspergillus niger and Saccharomyces cerevisiae. Global Journal of Biotechnology \& Biochemistry 9: 14-18. https://doi.org/10.5829/ idosi. gjbb.2014.9.1.82314

Bidlas E, Du T, Lambert RJW. 2008. An explanation for the effect of inoculum size on MIC and the growth/no growth interface. International Journal of Food Microbiology 126, 140-152. https://doi.org/10.1016/j.ijfoodmicro.2008.05.023

Chanda S, Chakrabarti S. 1996. Plant origin liquid waste: A resource for single-cell protein production by yeast. Bioresource Technology 57: 51-54. https://doi.org/10.1016/ 0960-8524(96)00053-3

Dewi ERS, Legowo AM, Izzati M. 2017. The use of non dairy creamer wastewater as the growth medium of Saccharomyces cerevisiae for single-cell protein production. Advanced Science Letters 23: 2438-2440. https://doi.org/10.1166/ asl.2017.8715

Dinarvand M, Rezaee M, Foroughi M. 2017. Optimizing culture conditions for production of intra and extracellular inulinase and invertase from Aspergillus niger ATCC 20611 by response surface methodology (RSM). Brazilian Journal of Microbiology 48: 427-441. https://doi.org/10.1016/j.bjm. 2016.10.026

Gao Y, Li D, Liu Y. 2012. Production of single cell protein from soy molasses using Candida tropicalis. Annals of Microbiology 62: 1165-1172. https://doi.org/10.1007/ s13213-011-0356-9

Gervasi T, Pellizzeri V, Calabrese G, Di Bella G, Cicero N, Dugo, G. 2018. Production of single cell protein (SCP) from food and agricultural waste by using Saccharomyces cerevisiae. Natural Product Research 32: 648-653. https://doi.org/ 10.1080/14786419.2017.1332617

Giavasis I, Petrotos K. 2016. Biovalorization of Olive Mill Waste Water for the Production of Single Cell Protein from Saccharomyces cerevisiae, Candida utilis and Pleurotus ostreatus. British Biotechnology Journal 11, 1-16. https://doi.org/10.9734/bbj/2016/22509

Haddish K. 2015. Production of Single Cell Protein from Fruit of Beles (Opuntia Ficus-Indica L.) Peels Using Saccharomyces cerevisiae. Journal of Microbiology \& Experimentation 2, 0 4. https://doi.org/10.15406/jmen.2015.02.00073

Hansen CL, Cheong DY. 2019. Agricultural waste management in food processing, in: Kutz, M. (Ed.), Handbook of Farm, Dairy and Food Machinery Engineering. Academic Press, pp. 673-716. https://doi.org/10.1016/B978-0-12-814803-7.00026-9

Hongpattarakere T, H-Kittikun A. 1995. Optimization of single-cellprotein production from cassava starch using Schwanniomyces castellii. World Journal of Microbiology \& Biotechnology 11: 607-609. https://doi.org/10.1007/ BF00360999

Hülsen T, Carvalho G, Egger F, Cruz H, Vertstraete W, Batstone DJ, Pikaar I. 2019. Production of single-cell proteins from organic matter and residual nitrogen, in: Olivares, J.A., Daniel, P., Melero, J.A., Dufour, J. (Eds.), Wastewater Treatment Residues as Resources for Biorefinery Products and Biofuels. Elsevier Inc., pp. 355-389. https://doi.org/ 10.1016/B978-0-12-816204-0.00016-3 
Ilgin M, Germec M, Turhan I. 2020. Statistical and kinetic modeling of Aspergillus niger inulinase fermentation from carob extract and its partial concentration. Industrial Crops and Products 156, 112866. https://doi.org/10.1016/ j.indcrop.2020.112866

Jiru TM, Melku B. 2018. Single Cell Protein Production from Torula Yeast (Cyberlindnera sp.) Using Banana Peel Hydrolysate. Journal of Advances in Microbiology 13: 1-7. https://doi.org/10.9734/jamb/2018/44801

Kapilan R, Rajendran S, Vasantharuba S. 2018. Single Cell Protein Production from Papaw and Banana Fruit Juices Using Baker's Yeast. American-Euroasian J. Agric. \& Environ. Sci 18: 168-172. https://doi.org/10.5829/ idosi.aejaes.2018.168.172

Khan M, Khan SS, Ahmed Z, Tanveer A. 2010. Production of Single Cell Protein from Saccharomyces cerevisiae by utilizing Fruit Wastes. Nanobiotechnica Universale 1: 127-132.

Khoshnevisan B, Tsapekos P, Zhang Y, Valverde-Pérez B, Angelidaki I. 2019. Urban biowaste valorization by coupling anaerobic digestion and single cell protein production. Bioresource Technology 290: 1-9. https://doi.org/10.1016/ j.biortech.2019.121743

Kornochalert N, Kantachote D, Chaiprapat S, Techkarnjanaruk S. 2014. Use of Rhodopseudomonas palustris P1 stimulated growth by fermented pineapple extract to treat latex rubber sheet wastewater to obtain single cell protein. Annals of Microbiology 64: 1021-1032. https://doi.org/10.1007/ s13213-013-0739-1

Kosseva MR. 2013. Recovery of Commodities from Food Wastes Using Solid-State Fermentation, in: Kosseva, M.R., Webb, C. (Eds.), Food Industry Wastes. Academic Press, pp. 77-102. https://doi.org/10.1016/B978-0-12-391921-2.00005-6

Kosseva MR. 2009. Processing of food wastes, in: Taylor, S. (Ed.), Advances in Food and Nutrition Research. Academic Press, 3, pp. 57-136. https://doi.org/10.1016/S1043-4526 (09)58003-5

Koutsoumanis KP, Sofos JN. 2005. Effect of inoculum size on the combined temperature, $\mathrm{pH}$ and a $\mathrm{w}$ limits for growth of Listeria monocytogenes. International Journal of Food Microbiology 104: 83-91. https://doi.org/10.1016/ j.ijfoodmicro.2005.01.010

Kurcz A, Błażejak S, Kot AM, Bzducha-Wróbel A, Kieliszek M. 2018. Application of Industrial Wastes for the Production of Microbial Single-Cell Protein by Fodder Yeast Candida utilis. Waste and Biomass Valorization 9: 57-64. https://doi.org/ 10.1007/s12649-016-9782-z

Mahan KM, Le RK, Wells T, Anderson S, Yuan JS, Stoklosa RJ, Bhalla A, Hodge DB, Ragauskas AJ. 2018. Production of single cell protein from agro-waste using Rhodococcus opacus. Journal of Industrial Microbiology and Biotechnology 45: 795-801. https://doi.org/10.1007/s10295018-2043-3

Mahat MS, MacRae IC. 1992. Rhizopus oligosporus grown on natural rubber waste serum for production of single cell protein: a preliminary study. World Journal of Microbiology \& Biotechnology 8: 63-64. https://doi.org/10.1007/ BF01200687

Mensah JKM, Twumasi P. 2017. Use of pineapple waste for single cell protein (SCP) production and the effect of substrate concentration on the yield. Journal of Food Process Engineering 40: 1-9. https://doi.org/10.1111/jfpe.12478

Milala MA, Yakubu M, Burah B, Laminu HH, Bashir H. 2018. Production and optimization of single cell protein from orange peels by Saccharomyces cerevisiae. Journal of Bioscience and Biotechnology Discovery 3: 99-104. https://doi.org/10.31248/jbbd2018.081

Mondal AK, Sengupta S, Bhowal J, Bhattacharya DK. 2012. Utilization of Fruit Wastes in Producing Single Cell Protein. International Journal of Science, Environment and Technology 1: 430-438.
Monkoondee S, Kuntiya A, Chaiyaso T, Leksawasdi N, Techapun C, Kawee-ai A, Seesuriyachan P. 2016. Treatability of cheese whey for single-cell protein production in nonsterile systems: Part II. The application of aerobic sequencing batch reactor (aerobic SBR) to produce high biomass of Dioszegia sp. TISTR 5792. Preparative Biochemistry and Biotechnology 46, 434-439. https://doi.org/10.1080/10826068.2015.1045612

Mujdalipah S, Putri ML. 2020. Utilization of pineapple peel and rice washing water to produce single cell proteins using Saccharomyces cerevisiae, in: IOP Conference Series: Earth and Environmental Science 472: 012029. https://doi.org/ 10.1088/1755-1315/472/1/012029

Munawar RA, Irfan M, Nadeem M, Syed QA, Siddique ZH. 2010. Biosynthesis of Single Cell Biomass of Candida Utilis By Submerged. Parkistan Journal of Science 62: 1-5.

Myint KT, Otsuka M, Okubo A, Mitsuhashi R, Oguro A, Maeda H, Shigeno T, Sato K, Nakajima-Kambe T. 2020. Isolation and identification of flower yeasts for the development of mixed culture to produce single-cell protein from waste milk. Bioresource Technology Reports 10: 100401. https://doi.org/ 10.1016/j.biteb.2020.100401

Nalage DN, Khedkar GD, Kalyankar AD, Sarkate AP, Ghodke SR, Bedre VB, Khedkar CD. 2016. Single Cell Proteins. Encyclopedia of Food and Health 4, 790-794. https://doi.org/ 10.1016/B978-0-12-384947-2.00628-0

Nasseri AT, Rasoul-Amini S, Morowvat MH, Ghasemi Y. 2011. Single cell protein: Production and process. American Journal of Food Technology 6: 103-116. https://doi.org/10.3923/ ajft.2011.103.116

Oshoma CE, Eguakun-Owie SO, Obuekwe IS. 2017. Utilization of banana peel as a substrate for Single cell protein and Amylase production by Aspergillus niger. African Scientist 18: $143-149$.

Patthawaro S, Saejung C. 2019. Production of single cell protein from manure as animal feed by using photosynthetic bacteria. MicrobiologyOpen 8: e913. https://doi.org/10.1002/mbo3.913

Putri D, Ulhidayati A, Musthofa IA, Wardani AK. 2018. Single cell protein production of Chlorella sp. using food processing waste as a cultivation medium, in: IOP Conference Series: Earth and Environmental Science 131012052. https://doi.org/10.1088/1755-1315/131/1/012052

Rajendran S, Kapilan R, Vasantharuba S. 2018. Papaw fruit juice as source for single cell protein production using natural palmyrah toddy yeast. Ceylon Journal of Science 47, 379386. https://doi.org/10.4038/cjs.v47i4.7556

Reihani SFS, Khosravi-Darani K. 2019. Influencing factors on single-cell protein production by submerged fermentation: A review. Electronic Journal of Biotechnology 37: 34-40. https://doi.org/10.1016/j.ejbt.2018.11.005

Ritala A, Häkkinen ST, Toivari M, Wiebe MG. 2017. Single cell protein-state-of-the-art, industrial landscape and patents 2001-2016. Frontiers in Microbiology 8. https://doi.org/ 10.3389/fmicb.2017.02009

Robinson TP, Aboaba OO, Kaloti A, Ocio MJ, Baranyi J, Mackey BM. 2001. The effect of inoculum size on the lag phase of Listeria monocytogenes. International Journal of Food Microbiology 70: 163-173. https://doi.org/10.1016/S01681605(01)00541-4

Saejung C, Salasook P. 2020. Recycling of sugar industry wastewater for single-cell protein production with supplemental carotenoids. Environmental Technology (United Kingdom) 41: 59-70. https://doi.org/10.1080/ 09593330.2018.1491633

Saejung C, Thammaratana T. 2016. Biomass recovery during municipal wastewater treatment using photosynthetic bacteria and prospect of production of single cell protein for feedstuff. Environmental Technology 37: 3055-3061. https://doi.org/10.1080/09593330.2016.1175512 
Said SD, Zaki M, Novita E, Asnawi TM. 2019. Production of single cell protein by a local Trichoderma reesei in solid state fermentation: effects of process variables, in: Journal of Physics: Conference Series 1376 (2019) 012043. pp. 8-13. https://doi.org/10.1088/1742-6596/1376/1/012043

Samadi S, Mohammadi M, Najafpour GD. 2016. Production of single cell protein from sugarcane bagasse by Saccharomyces cerevisiae in tray bioreactor. International Journal of Engineering 29: 1029-1036. https://doi.org/10.5829/ idosi.ije.2016.29.08b.00

Shahi P, Kim SC, Haliburton JR, Gartner ZJ, Abate AR. 2017. Abseq: Ultrahigh-throughput single cell protein profiling with droplet microfluidic barcoding. Scientific Reports 7: 112. https://doi.org/10.1038/srep44447

Shete D, Raut S. 2018. Isolation and Identification of Organisms and Production of Single Cell Protein by Using Natural Gas. International Journal of Current Microbiology and Applied Sciences 7: 1778-1787. https://doi.org/10.20546/ ijcmas.2018.712.207

Skandamis PN, Stopforth JD, Kendall PA, Belk KE, Scanga JA, Smith GC, Sofos JN. 2007. Modeling the effect of inoculum size and acid adaptation on growth/no growth interface of Escherichia coli O157:H7. International Journal of Food Microbiology 120: 237-249. https://doi.org/10.1016/ j.ijfoodmicro.2007.08.028

Spalvins K, Ivanovs K, Blumberga D. 2018a. Single cell protein production from waste biomass: Review of various agricultural by-products. Agronomy Research 16: 1493 1508. https://doi.org/10.15159/AR.18.129

Spalvins K, Ivanovs K, Blumberga D. 2018b. Single cell protein production from waste biomass: review of various agricultural by-products. Agronomy Research 16: 1493 1508. https://doi.org/https://doi.org/10.15159/AR.18.129

Steinberg LM, Kronyak RE, House CH. 2017. Coupling of anaerobic waste treatment to produce protein- and lipid-rich bacterial biomass. Life Sciences in Space Research 15: 32 42. https://doi.org/10.1016/j.lssr.2017.07.006
Suman G, Nupur M, Anuradha S, Pradeep B. 2015. Single Cell Protein Production: A Review. International Journal of Current Microbiology and Applied Sciences 4: 251-262. https://doi.org/10.1016/S0167-8760(01)00179-9

Valverde-Pérez B, Pape ML, Kjeldgaard AF, Zachariae AA, Schneider C, Hélix-Nielsen C, Zarebska A, Smets BF. 2020. Dewatering methanotrophic enrichments intended for single cell protein production using biomimetic aquaporin forward osmosis membranes. Separation and Purification Technology 235. https://doi.org/10.1016/j.seppur.2019.116133

Wainaina S, Kisworini AD, Fanani M, Wikandari R, Millati R, Niklasson C, Taherzadeh MJ. 2020. Utilization of food waste-derived volatile fatty acids for production of edible Rhizopus oligosporus fungal biomass. Bioresource Technology 310: 123444. https://doi.org/10.1016/ j.biortech.2020.123444

Xu M, Zhou H, Yang X, Angelidaki I, Zhang Y. 2020. Sulfide restrains the growth of Methylocapsa acidiphila converting renewable biogas to single cell protein. Water Research 184: 116138. https://doi.org/10.1016/j.watres.2020.116138

Yadav JSS, Yan S, Pilli S, Kumar L, Tyagi RD, Surampalli RY. 2015. Cheese whey: A potential resource to transform into bioprotein, functional/nutritional proteins and bioactive peptides. Biotechnology Advances 33: 756-774. https://doi.org/10.1016/j.biotechadv.2015.07.002

Yousufi MK. 2012. To Determine Protein Content of Single Cell Protein Produced By Using Various Combinations. International Journal of Advanced Biotechnology and Research 3: 533-536.

Yunus F, Nadeem M, Rashid F. 2015. Single-cell protein production through microbial conversion of lignocellulosic residue (wheat bran) for animal feed. Journal of the Institute of Brewing 121: 553-557. https://doi.org/10.1002/jib.251

Zhou YM, Chen YP, Guo JS, Shen Y, Yan P, Yang JX. 2019. Recycling of orange waste for single cell protein production and the synergistic and antagonistic effects on production quality. Journal of Cleaner Production 213: 384-392. https://doi.org/10.1016/j.jclepro.2018.12.168 